\title{
HeLa is not a Cervical Carcinoma but a Human Breast Cancer Cell Line
}

\author{
Sen Pathak* \\ Department of Genetics, University of Texas M D Anderson Cancer Center, USA \\ *Corresponding author: Sen Pathak, Department of Genetics, The University of Texas M. D. Anderson Cancer Center, Houston, \\ Texas 77030, USA. \\ To Cite This Article: Sen Pathak. HeLa is not a Cervical Carcinoma but a Human Breast Cancer Cell Line. Am J Biomed Sci \& Res. 2021 - 14(3). \\ AJBSR.MS.ID.001996. DOI: 10.34297/AJBSR.2021.14.001996.
}

Received: 阱June 11, 2020; Published: 製 October 06, 2021

\section{Opinion}

Human cancer cell lines, such as the HeLa line established in culture by George Otto Gey and associates [1], are of paramount importance in biomedical research. HeLa is the first human cancer cell line ever established in culture from the so-called cervical biopsy obtained from a 31-year-old African American woman named, Henrietta Lacks. Henrietta died within eight months of her widespread cancer diagnosis. From the very beginning, the pathology of HeLa was in doubt. Howard W. Jones, Jr, the original gynecologist who examined Henrietta first, wrote a reappraisal 20 years later on the origin of HeLa and said, "On palpation, the lesion was so soft that it was scarcely recognizable to the examining finger. The remainder of the pelvic examination was unrevealing. The examiner, who considered himself not without experience in the appearance of cervical cancer, was quite concerned that the unusual appearance of this lesion was not consistent with the diagnosis of cancer. At a loss for a proper diagnosis, the possibility of a primary cancer of the cervix was considered, although neither before nor since has the examiner ever seen one." In the same article Jones and associates [2] further wrote, "However, many of the cells show a telltale acinous formation with clear gland cells growing directly from the ordered glandular cords into sheets which were misinterpreted and mislabeled two decades ago as epidermoid carcinoma. HeLa is without a doubt, in the opinion of Dr. J. Donald Woodruff and this gynecologist, a very aggressive adenocarcinoma of the cervix." This was the second time the histopathology of HeLa was changed.
HeLa cells known to contaminate several human and other mammalian cell lines because of their aggressiveness in cell cultures. HeLa cell contamination to other human heteroploid cell lines is based on three characteristics: (i) presence of the characteristic HeLa marker chromosomes [3], (ii) presence of glucose-6-phosphate dehydrogenase (G6PD) a isoenzyme [4] and (iii) the absence of $\mathrm{Y}$ chromosome in male-derived human cancer cell lines with multiple $\mathrm{X}$ chromosomes [5]. In February 1979, a paper entitled, "A Human Breast Adenocarcinoma with Chromosome and Isoenzyme Markers Similar to those of the HeLa Line" was published on the directly processed pleural effusion obtained from a 51-year-old black woman for chromosomal and isoenzyme analysis [6]. From the same effusion, a continuously growing permanent breast cancer cell line (MDA-MB-468) was also available for its chromosomal and isoenzyme evaluation. Presence of six typical HeLa marker chromosomes and isoenzyme A type G6PDH mobility in this sample questioned the origin of HeLa cell pathology. Further analyses of additional breast cancer samples harvested directly or from the established breast cancer cell lines have revealed the presence of some of these characteristic typical HeLa chromosome markers [5, 7-18]. This does not mean that HeLa has not contaminated human cancer cell lines originating from other organs. Unfortunately, it has contaminated many human cancer cell lines [4, 5, 13-16 \&19-25]. Human cervical cancer cell lines studied by other investigators for their chromosomal characteristics have shown their own common markers but have no similarity and 
commonality with any Hela marker chromosomes [26-30]. There is hardly any human cervical cancer cell line described in the literature that contaminated with Hela. On the other hand, a large number of human breast cancer cell lines are shown to be contaminated with HeLa.

If the HeLa cell line has originated from the cervical biopsy of Henrietta Lacks then, it must show some similarity of markers with the marker chromosomes of other cervical cancer cell lines, but it does not [27-30]; rather it showed similarity and commonality of marker chromosomes with the bona fide breast cancer cell lines and directly processed pleural effusions from breast cancer patients.

Breast cancer cells are known to metastasize to cervices but it is a rare phenomenon (Personal communications with many expert Pathologists of the world). There are very few cervical carcinoma cell lines available as compared to breast cancer because of the difficulty of growing such cells in culture. We, therefore, conclude that HeLa has its origin from the breast cancer. Henrietta Lacks died at the tender age of 31 years within 8 months of diagnosis with wide spread disease.

Our conclusion based on the following similarities between HeLa and other human breast cancer cell lines:

i. Both have 5 to 6 common marker chromosomes

ii. Both HeLa and MDA-MB-648 cell lines share common G6PDH mobility of A type

iii. Another Isoenzyme MGM1 is present in both

iv. Cervical tumor is very rare compared to breast cancer in USA

v. More breast cancer cell lines as compared to cervical cancer lines are contaminated with HeLa

vi. Both cell lines HeLa and MDA-MB-468 originated from African American patients

vii. HeLa and MDA-MB-468 have identical 12 isoenzymes

viii. Breast cancer does metastasize into human cervical area as HeLa

ix. Both HeLa and MBA-MB-468 cell lines are derived from metastatic and very aggressive samples and established in culture rather easily

$\mathrm{x}$. According to the grand- and great granddaughters of Henrietta Lacks, more breast cancers compared to cervical, have occurred in members of her family [31]

It is, therefore recommended that investigators as an example of human breast cancer and not a representative of cervical cancer should use original HeLa cell line. It is unfortunate that despite our warning, some investigators are still using HeLa in the name of cervical cancer.

\section{Acknowledgments}

The author is grateful to Cynthia Burr Furlong and Asha $S$ Multani for their editorial corrections.

\section{References}

1. GO Gey, WD Coffman, MT Kubicek (1952) Tissue culture studies of the proliferative capacity of cervical carcinoma and normal epithelium. Cancer Res 12: 264-265.

2. HW Jones, Jr, VA McKusick, PS Harper, KD Wuu (1971) George Otto-Gey (1899-1970). The HeLa cell and a reappraisal of its origin. Obstet and Gynecol 38: 945-949.

3. OJ Miller, DA Miller, PW Allderdice, VG Dev, MS Grewal (1971) Quinacrine fluorescent karyotypes of human diploid and heteroploid cell lines. Cytogenetics 10: 338-346.

4. SM Gartler (1968) Apparent HeLa cell contamination of human heteroploid cell lines. Nature 217: 750-751.

5. WA Nelson-Rees, RR Flandermeyer, PK Hawthorne (1975) Distinctive banded marker chromosomes of human tumor cell lines. Int J Cancer 16: 74-82.

6. S Pathak, MJ Siciliano, R Cailleau, CL Wiseman, TC Hsu (1979) A human breast adenocarcinoma with chromosome and isoenzyme markers similar to those of the HeLa line. J Natl Cancer Inst 62: 263-271.

7. S Kakati, I Hayata, M Oshimura, AA Sandberg (1975) Chromosomes and causation of human cancer and leukemia. X. Banding patterns in cancer effusions. Cancer 36: 1729-1738.

8. QVJ Cruciger, S Pathak, R Cailleau (1976) Human breast carcinomas: marker chromosomes involving 1q in seven cases. Cytogenet Cell Genet 17: 231-235.

9. S Pathak (1980) Cytogenetic analysis in human breast tumors. Cancer Genet Cytogenet 1: 281-289.

10. KL Satya-Prakash, S Pathak, TC Hsu, M Olive, R Cailleau (1981) Cytogenetic analysis on eight human breast tumor cell lines: High frequencies of 1q, 11q and HeLa-like marker chromosomes. Cancer Genet Cytogenet 3: 61-73.

11. DB Krizman, NJ Carpenter, S Pathak, M Olive, R Cailleau et al. (1987) HeLa marker chromosomes in human breast tumors: Proposal about the origin of the HeLa cell line. J Clinical Lab Analysis 1: 93-97.

12. G Seman, SJ Hunter, RC Miller, L Dmochowski (1976) Characterization of an established cell line (SH-3) derived from pleural effusion of patient with breast cancer. Cancer 37: 1814-1824.

13. WA Nelson-Rees, RR Flandermeyer, PK Hawthorne (1974) Banded marker chromosomes as indicators of intraspecies cellular contamination. Science 184: 1093-1096.

14. CC Lin, S Goldstein (1974) Analysis of Q-banding patterns in human cell lines. J Natl Cancer Inst 53: 298-304.

15. WK Heneen (1976) The chromosome complement of a measle- carrier human cell line in comparison to the cell line of origin. Hereditas 82: 217-248.

16. KS Lavappa, ML Macy, JE Shannon (1976) Examination of ATCC stock for HeLa marker chromosomes in human cell lines. Nature 259: 211-213.

17. WA Nelson-Rees, RR Flandermeyer (1976) HeLa cultures defined. Science 191: 96- 98. 
18. WA Nelson-Rees, RR Flandermeyer (1977) Inter- and intra-species contamination of human breast tumor cell lines $\mathrm{HBC}$ and $\mathrm{BrCa} 5$ and other cell cultures. Science 195: 1343-1344.

19. WA Nelson-Rees, RR Flandermeyer, DW Daniels (1980) T-1 cells are HeLa and not of normal human kidney origin. Science 209: 719-720.

20. WA Nelson-Rees, DW Daniels, RR Flandermeyer (1981) Cross-contamination of cells in culture. Science 212: 446-452.

21. G Buehring, E Eby, M Eby (2004) Cell line cross-contamination: how aware are mammalian cell culturists of the problem and how to monitor it? In Vitro Cell Dev Biol Anim 40: 211-215.

22. R Nardone (2008) Curbing rampant cross-contamination and misidentification of cell lines. Biotechniques 45: 221-227.

23. BP Lucey, WA Nelson-Rees, GM Hutchins (2009) Henerietta Lacks, HeLa cells and cell culture contamination. Arch Pathol Lab Med 133: 1463 1467

24. A Capes-Davis, G Theodosopoulos, I Atkin, HG Drexler, A Kohara A, et al. (2010) Check your cultures! A list of cross-contaminated or misidentified cell lines. Int J Cancer 127: 1-8.

25. Y Reid (2011) Characterization and authentication of cancer cell lines: An overview. Methods Mol Biol 731: 35-43.
26. MR Bordelon, E Stubblefield (1974) Human tumors in mice confirmed by chromosomal analysis. Nature 252: 324-326.

27. F Herz, OJ Miller, DA Miller, N Auersperg, LG Koss (1977) Chromosome analysis and alkaline phosphatase of C41, a cell line of human cervical origin distinct from HeLa. Cancer Res 37: 3209-3213.

28. NB Atkin, MC Baker (1979) Chromosome 1 in 26 carcinomas of the cervix uteri: structural and numerical changes. Cancer 44: 604-613.

29. S Pathak, TC Hsu (1980) Cytogenetic analysis in human neoplasia with special reference to breast and female genital tumors. In: Cell Biology of Breast Cancer: Systematics of mammary cell transformation, CM McGrath, MJ Brennan, MA Rich (Eds.), Academic Press, New York, pp 57-75.

30. RS Freedman, JM Bowen, A Leibovitz, S Pathak, MJ Siciliano et al. (1982) Characterization of a cell line (SW-756) derived from a human squamous carcinoma of the uterine cervix. In Vitro 18: 719-726.

31. S Pathak (2021) Cancer cell lines: Its implication for therapeutic use. In: Cancer diagnostics and therapeutics- current trends, challenges and future. SK Basu, CK Panda, S Goswami (Eds.) Springer Nature Singapore Pte Ltd. (in press). 